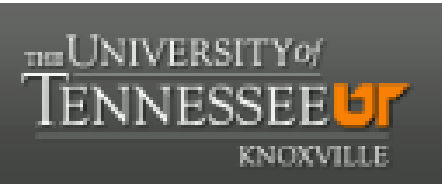

University of Tennessee, Knoxville

TRACE: Tennessee Research and Creative

Exchange

January 2003

\title{
Counting on the Past or Investing in the Future? Economic and Political Accountability in Fujimori's Peru
}

Jana Morgan

University of Tennessee, Knoxville, janamorgan@utk.edu

Follow this and additional works at: https://trace.tennessee.edu/utk_polipubs

Part of the Political Science Commons

\section{Recommended Citation}

Morgan, Jana, "Counting on the Past or Investing in the Future? Economic and Political Accountability in Fujimori's Peru" (2003). Political Science Publications and Other Works.

https://trace.tennessee.edu/utk_polipubs/12

This Article is brought to you for free and open access by the Political Science at TRACE: Tennessee Research and Creative Exchange. It has been accepted for inclusion in Political Science Publications and Other Works by an authorized administrator of TRACE: Tennessee Research and Creative Exchange. For more information, please contact trace@utk.edu. 


\title{
Counting on the Past or Investing in the Future? Economic and Political Accountability in Fujimori's Peru
}

\author{
Jana Morgan Kelly \\ University of North Carolina at Chapel Hill
}

This article strengthens and extends economic theories of presidential approval, assesses accountability in Peru's "delegative democracy," and explores the political feasibility of economic policies. The analysis finds that prospective evaluations shape presidential approval in Peru, demonstrating the utility of economic theories in the developing world. Peruvians hold politicians accountable not only for the economic past, but also for future implications of past actions, which suggests that vertical accountability exists and that this type of accountability encourages forward-looking policy choices. Finally, the analysis indicates that important political events, including the capture of the Sendero Luminoso guerrillas and Fujimori's autogolpe, influence Peruvians' approval of the president.

\section{Economic Accountability and Presidential Approval}

\begin{abstract}
A
ccountability is central to democratic politics because without it, democracy and representation are mere facades (Schedler, Diamond, and Plattner 1999). One of the central aspects of accountability is the vertical relationship between the people and their representatives (Schedler 1999). Vertical accountability requires that public officials are motivated to consider the wishes of the people when making decisions. In order for this motivation to exist, officials must believe that the public will somehow reward or punish them for their decisions. Elections are the most obvious source of this motivation, but considerations such as maintaining sufficient political capital to enact policy goals or even preventing possible coup attempts may also provide officials with reason to care about public opinion.
\end{abstract}

Previous versions of this article were presented at the 59th Annual Meeting of the Midwest Political Science Association in 2001, and the 23rd Congress of the Latin American Studies Association in 2001. I am grateful to John Booth, David Lowery, Lars Schoultz, Elizabeth Zechmeister, and especially Evelyne Huber, Nathan Kelly, and Jim Stimson for their helpful and insightful comments on earlier drafts. The Tinker Foundation and the University of North Carolina's Institute of Latin American Studies provided financial support for field research and data collection. 
However, vertical accountability also necessitates that the public as a whole develop evaluations of elected officials that are somehow based on their actions while in office. If public approval is merely arbitrary, elected officials may act however they wish because they will find it difficult if not impossible to align their actions with a capricious public and will, therefore, cease to be motivated to care about public opinion. Thus, without a responsive public, vertical accountability will fail.

Demonstrating that there is a systematic foundation for the public's evaluations of elected officials provides evidence that vertical accountability is possible. In this article, I examine the economy as a likely foundation for the Peruvian public's assessments of the president. Making fiscal and monetary policies is one of the primary functions of government, and the outcomes of these policies affect the national economy and the economic well-being of individual citizens (Hibbs 1987). These outcomes are some of the most visible and quantifiable government outputs, facilitating evaluation of success or failure. Furthermore, a substantial body of research has pointed to the economy as an important basis for assessments of elected officials (Duch 1995; Eulau and Lewis-Beck 1985; Kinder and Kiewiet 1981; Lewis-Beck 1988; Shapiro and Conforto 1980).

If a public's assessments of its leaders can be shown to be connected to the economy, then we have evidence of vertical accountability. Previous research has conceptualized citizens' evaluations of the economy as the link between the economy and political assessments. ${ }^{1}$ However, a debate has developed over the type of economic evaluations the public uses when assessing its leaders. When appraising politicians' performance, do people look to the past and use retrospective evaluations, or do they look to future potential and employ prospective evaluations? ${ }^{2}$ Both types of evaluations can be used to demonstrate that citizens hold politicians accountable for the economy although the exact nature of the accountability process may vary depending on the type of evaluations employed. Therefore, examining whether and how the two types of economic evaluations shape political assessments is a crucial element in understanding the extent and nature of accountability (Chappell and Keech 1985).

Essentially, the retrospective view of the connection between economics and political assessments conceives of citizens rewarding incumbents for good

\footnotetext{
${ }^{1}$ The most basic models of the relationship between economics and public evaluations of political leaders simply use real economic indicators as the independent variables of interest. The findings of these studies are largely inconclusive. Some find significant effects for at least some of the indicators (Monroe 1978; Pacek 1994; Pacek and Radcliff 1995), and others argue that economic indicators do not explain approval (Norpoth and Yantek 1983). Often, measures of the real economy are included as controls but are not expected to provide significant explanatory leverage. Inflation and GDP per capita are treated as such in this study of Peruvian presidential approval.

${ }^{2}$ The question of whether citizens are concerned more with their own economic situation (pocketbook evaluations) or with the national economy (sociotropic evaluations) has also received considerable scholarly attention (Kinder 1981; Lewis-Beck 1985). This analysis cannot address this issue because sociotropic evaluations are not available for Peru.
} 
economic performance and punishing them for poor outcomes (Key 1966). Fiorina (1981) presents a slightly more complex conceptualization, arguing that citizens use retrospective evaluations to extrapolate about the future and then assess politicians based on these extrapolations. The retrospective link between economic and political assessments evokes the traditional understanding of accountability, wherein incumbents are held responsible for past actions and policies.

Alternatively, proponents of the prospective connection between economics and politics assert that the public uses more than the past in judging incumbents (Kuklinski and West 1981; Lewis-Beck 1988; MacKuen, Erickson, and Stimson 1992). Rather, people develop economic expectations, which are formulated using retrospections as well as all other available information such as economic forecasts and economic indicators (Erickson, MacKuen, and Stimson 2002). While this view does not negate the idea that the public holds politicians accountable for the past, ${ }^{3}$ prospective accountability suggests that leaders are also assessed for future consequences of past actions.

The debate over whether citizens are solely retrospective or if prospective evaluations also matter remains largely unresolved. Pursuing understanding of exactly how economics influence presidential approval is important because it sheds light on the central issue of democratic politics - whether and how citizens achieve representation and accountability in government (Conover, Feldman, and Knight 1987).

This article explores these issues of economic accountability in Peru, which presents an especially important and challenging framework for such issues. First, the fragility and volatility of the economic and political realms in developing countries like Peru make them particularly rigorous tests of economic accountability theories, which were developed largely in the context of advanced, industrialized democracies (Pacek and Radcliff 1995). Previous research indicates that the economy influences policy, electoral outcomes, and support for democracy in the developing world (Duch 1995; Kaufman and Zuckerman 1998; Pacek 1994; Remmer 1991, 1993; Seligson and Gómez 1989; Stokes 1996). However, with a few notable exceptions (e.g., Weyland 1998) this research does not explore the effects of retrospective and prospective evaluations to determine exactly how politicians are held accountable for the economy. Therefore, differentiating between retrospective and prospective evaluations in this analysis of presidential approval in Peru enables us to test and extend the theories of economic accountability.

Second, matters of accountability are extremely salient in precarious democracies like Peru, as they struggle to implement effective means of holding government answerable to the citizenry (Sartori 1987; Schedler, Diamond, and Plattner 1999; Stokes 1999). Peru, like many of its Latin American neighbors,

\footnotetext{
${ }^{3}$ In fact, most studies that find prospective evaluations to be important also find significant effects for retrospective evaluations.
} 
exhibits the characteristics of "delegative democracy" (O’Donnell 1999). In delegative democracies, the democratic institutions, such as legislatures and courts, that typically provide avenues for accountability and representation are viewed as nuisances and rendered irrelevant. The president is the sole political actor, so the relationship between the people and their leader is the only possible link of accountability. If vertical accountability between the president and the public does not exist, then there is likely little democracy beyond the ballot box. Therefore, determining if and how the president is held accountable are crucial elements in understanding the quality of democracy in these countries.

Finally, understanding how economic accountability functions in the uncertain economic environment of developing countries provides important information about the types of economic policies that are politically feasible. For example, it is unlikely that unsustainable growth or economic maneuvering will fool a forward-looking public, but political exploitation of the economy may deceive a purely retrospective one (Chappell and Keech 1985). Alternatively, a prospective public is much more likely to endure temporary hardship for expected economic gains (Przeworski 1991). The austerity programs, which have by now become almost imperative in much of the developing world, will be more palatable if the public is prospective in its orientation.

Therefore, while this study deepens our understanding of accountability in Peru, it does much more. It strengthens and extends our theories of economic accountability, explores the possibility of accountability in delegative democracies, and provides insight into the political viability of certain economic policies.

\section{Political Accountability and Presidential Approval}

\section{Events in Peruvian Politics}

Economic factors are of central interest in this study, but many analyses of public opinion in Peru emphasize specific events and noneconomic factors (McClintock 1999; Panfichi 1997). One event that is mentioned repeatedly in the literature is the autogolpe of April 5, 1992, when President Alberto Fujimori closed Congress and suspended the constitution (Contreras and Cueto 1999; McClintock 1999; Panfichi 1997). The public responded to this authoritarian move with overwhelming approval, and it has been linked statistically to a significant jump in Fujimori's popularity (Stokes 1996; Weyland 2000).

Other occurrences during the series that may influence approval ratings include the 1995 border conflict with Ecuador (Klepak 1998; Marcella and Downes 1999), Fujimori's reelection in 1995, and the 1996 invasion of the Japanese ambassador's residence by the Tupac Amaru Revolutionary Movement (Contreras and Cueto 1999; Weyland 2000). A complete explanation of presidential approval in Peru during the period would consider these events, and they are addressed in the analysis below. Addressing the role of events in shaping the fortunes of leaders broadens our understanding of how certain incidents influence 
the thinking of the Peruvian public. However, it seems unlikely that this type of case-specific, idiosyncratic explanation wields the same leverage in understanding over-time variation in approval levels as the economic explanation does. So the core of the full model is the relationship between the economy and approval, with the event factors supplementing the analysis and allowing for better model specification.

\section{Sendero Luminoso and Political Violence}

Since the transition from military to civilian rule in 1980, Peru has suffered from serious guerrilla insurgencies that controlled broad swaths of territory and undermined national consolidation. When President Fujimori took office in 1990, the most militant and successful of these guerrilla groups, the Maoist Sendero Luminoso (Shining Path), had almost completely incapacitated the state and seemed poised to take over the governing apparatus (Burt 1997; McClintock 1999). As the violence and attendant fear intensified, citizens began to question the capacity of the state to deal with the guerrilla threats, and many came to fear the state apparatus itself (Burt 1997; McClintock 1998). Indeed, it seems as if Peru narrowly escaped complete state collapse when the anti-terrorist police located the safe house of Abimael Guzmán, Sendero's authoritarian leader, and captured him on September 12, 1992. Shortly thereafter, more than 1,000 other suspected Senderistas were arrested based on information found in the safe house. Some attempts were made by the remaining militants to persevere in the revolution, but the loss of Guzmán was never overcome, and the credibility of Sendero's threat diminished significantly (McClintock 1998, 91).

The fear and uncertainty that accompanied Sendero's activity and the failure of the state to resolve the crisis undermined support for the government and translated into disapproval of political leaders. Alternatively, most Peruvians felt a great sense of relief and gratitude when Guzmán was captured. Some measure of political violence or perceived violence should be included in any model of Peruvian presidential approval during the period of Sendero activity. One possibility might be to incorporate a count of the number of terrorist acts each month or survey responses to questions about the impact of the violence, but monthly measures like these are not available for the full time-series under analysis here. ${ }^{4}$ Additionally, because the data series employed does not begin until December 1991, fewer than 12 of the observations occur during the period of concentrated violence, which does not allow exploration of how violence shaped approval. The most direct and feasible way to address Sendero's impact is to include a variable that accounts for the immediate decrease in violence and the movement's

\footnotetext{
${ }^{4}$ Weyland (2000) employs a question that examines people's approval of the anti-guerrilla policy and finds that this variable does not influence presidential approval. However, this question does not tap the extent to which people's lives were disrupted by Sendero activity, only if they approved of government actions to combat it. Weyland does find that the capture of Guzmán had the effect of temporarily boosting Fujimori's approval.
} 
disappearance following Guzmán's capture. To tap how the public's ensuing gratitude influenced Fujimori's approval, I use intervention analysis and then incorporate the intervention into the full model.

\section{Assessing Vertical Accountability in Peru}

Previous research on Peru has established that the economy provides a systematic foundation for the public's evaluations of the president (Stokes 1996; Weyland 2000). Stokes (1996) finds that increases in inflation are associated with decreases in support for the president, and Weyland (2000) demonstrates that support for the president's economic policy is a significant predictor of presidential approval. However, these studies do not unravel how the public uses the economy to assess the president because they do not examine and compare the impact of different types of economic evaluations. By assessing the influence of retrospective and prospective evaluations on presidential approval, this article unravels the nature of economic accountability in Peru.

\section{Data and Measurement}

This analysis examines presidential approval ratings for the period December 1991 through April 2000. The survey data used here come from monthly public opinion polls conducted by Apoyo, S.A., a respected Peruvian public opinion and market research firm, in which a random sample of Greater Lima residents answers a series of questions concerning various public issues. Here the individual-level data are aggregated such that there is a single score on each variable for each month. ${ }^{5}$ As the dependent variable, I analyze monthly approval ratings for President Fujimori. ${ }^{6}$ Approval is measured as the percentage of all respondents who indicate approval of the president's current performance. The black line in Figure 1 shows this approval rating from December 1991 to April 2000. The mean approval rating for this period is $57 \%$.

Turning to the economic independent variables, the measures of inflation and $\boldsymbol{G D P}$ are compiled by the Peruvian National Institute for Statistics and Information. ${ }^{7}$ As with presidential approval, the measures for prospective and retrospec-

\footnotetext{
${ }^{5}$ The sample size of approximately 500 respondents yields point estimates with larger confidence intervals and thus more noise, or measurement error, than a larger sample might. This provides a rather conservative test of the theories explored.

${ }^{6}$ The question used is: "In general, would you say that you approve or disapprove of the current performance of Alberto Fujimori?"

${ }^{7}$ For proper model specification and causal ordering, both inflation and GDP are lagged one period. GDP is also differenced to achieve stationarity. Assessment of the GDP series also indicates that seasonal error processes are at work. The analysis presented below does not address the seasonality issue because in the process of deseasonalizing the series, twelve time points are lost. The loss of this year of data is particularly problematic because both the self-coup and the capture of Guzmán take place in this period. Nevertheless, models that use deseasonalized GDP produce nearly identical results to those presented below which use lagged, differenced GDP.
} 
FIGURE 1

\section{Presidential Approval with Retrospective and Prospective Evaluations}

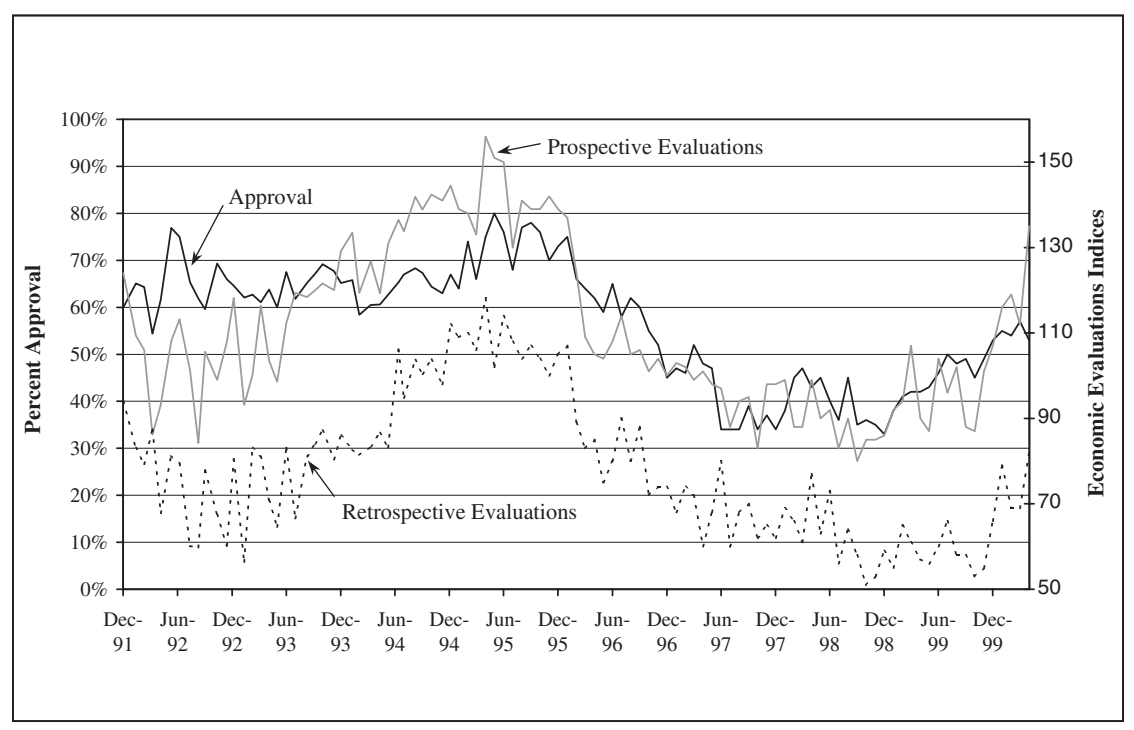

tive economic evaluations are taken from Apoyo's monthly public opinion surveys. From these measures, I construct indices for both retrospective and prospective evaluations. ${ }^{8}$ Figure 1 displays the Prospective and Retrospective Evaluation Indices with presidential approval ratings. The trends in the three series are similar: after short periods of decline, all three increase until mid-1995 when they again start a decline that continues until near the end of the series. These visual trends seem to support the notion that economic evaluations and presidential approval are related, but the evidence is crude, and a more systematic examination of the relationships is necessary. I now proceed to this analysis.

\section{Analysis}

Although the central focus of this analysis is the interplay between economics and presidential approval, I first examine the political factors discussed above to

\footnotetext{
${ }^{8}$ The questions used to tap retrospective and prospective evaluations are: "How is your family's economic situation in relation to six months ago: better, the same or worse?" and "How do you think your family's economic situation will be six months from now: better, the same or worse?" The indices are computed by adding to 100 the percentage of respondents giving positive evaluations and then subtracting the percentage reporting negative evaluations. The indices range, theoretically, from 0 to 200 with higher values indicating more positive evaluations. Both indices are differenced to achieve stationarity.
} 
assure proper model specification and to understand their impact on approval. Using intervention analysis, I assess the impact and duration of these events' influence on approval. Those that are found to have significant effects are incorporated into the subsequent economic models. I then turn to time-series regression analysis of the full model.

POLITICAL EVENTS AND PRESIDENTIAL APPROVAL: AN INTERVENTION ANALYSIS. ${ }^{9}$ Intervention analysis in the Box-Tiao (1975) tradition allows the researcher to assess the influence of a particular event (or intervention) on a time-series, dependent variable. The approach enables investigation not only of the magnitude of an event's effect, but also of its duration and character. This method is ideal for exploring exactly how Fujimori's approval was shaped by events that have been argued to be important for his popularity.

As noted above, most scholars of Peruvian politics consider the arrest of the Sendero Luminoso leaders in September 1992 a pivotal event for the nation, and many scholars have argued that it was crucial in bolstering support for the president (McClintock 1999; Stokes 1996). Thus, we expect this analysis to confirm the hypothesis that the guerrillas' capture was associated with a significant jump in Fujimori's popularity. Our expectations about the magnitude and duration of the effect are less clear, but the intervention analysis should provide useful insight here.

Examination of Table 1, which displays examples of several different intervention models, indicates that the hypothesis concerning the initial impact of the guerrillas' capture is confirmed. The analysis demonstrates that regardless of model specification, the initial effect of the arrests is positive and significant. Under most specifications, the intervention coefficient is .10, significant at least at the .05 level. Substantively, this means that the arrest of Guzmán precipitated a 10-point increase in Fujimori's approval.

But does this effect dissipate quickly or endure for some time? I find that the influence of the Sendero arrests on Fujimori's popularity persists. The decay rate of this 10-point increase ranges from about .60 to .98 , depending on the particular model. The significant decay rates, as well as the most common, were over .9 , and all the rates were within two standard deviations of one. ${ }^{10}$ These results indicate that the approval boost from the guerrillas' capture was not simply fleeting. Based on Model 4, one year after Guzmán's capture, Fujimori was enjoying an estimated eight-point boost over what his approval would have been without the capture, and at the time of his reelection in 1995, he was still experiencing an increase of six points. Five years after the event, he still had three extra approval points. In contrast to earlier research, which uses time-series regression to argue that the influence of Guzmán's capture was only fleeting (Weyland 2000), these findings lead me to conclude that not only was the arrest temporarily impor-

\footnotetext{
${ }^{9}$ This analysis was conducted using WinRATS, version 4.31.

${ }^{10} \mathrm{~A}$ decay rate of one indicates that the impact never decays; it has a permanent effect.
} 
TABLE 1

Presidential Approval: Box-Tiao Intervention Analysis

\begin{tabular}{|c|c|c|c|c|c|c|c|}
\hline \multirow[b]{2}{*}{ Independent Variable } & \multicolumn{7}{|c|}{ Presidential Approval } \\
\hline & 1 & 2 & 3 & 4 & 5 & 6 & 7 \\
\hline Sendero, impact & $\begin{array}{c}9.3^{*} \\
(4.68)\end{array}$ & $\begin{array}{l}10.2 * \\
(4.52)\end{array}$ & $\begin{array}{l}11.4^{* *} \\
(4.43)\end{array}$ & $\begin{array}{l}10.4^{* *} \\
(4.39)\end{array}$ & & & \\
\hline Sendero, decay & $\begin{array}{c}.59 \\
(.51)\end{array}$ & $\begin{array}{l}.99 * * \\
(.02)\end{array}$ & $\begin{array}{c}.61 \\
(.38)\end{array}$ & $\begin{array}{l}.98 * * \\
(.02)\end{array}$ & & & \\
\hline Self-coup, impact & & $\begin{array}{l}15.9 * * \\
(4.54)\end{array}$ & $\begin{array}{l}17.1^{* *} \\
(5.06)\end{array}$ & $\begin{array}{l}15.9 * * \\
(4.37)\end{array}$ & $\begin{array}{l}15.4 * * \\
(4.6)\end{array}$ & & $\begin{array}{l}15.4^{*} \\
(4.4)\end{array}$ \\
\hline Self-coup, decay & & $\begin{array}{l}.70^{* *} \\
(.26)\end{array}$ & $\begin{array}{l}1.07 * * \\
(.00)\end{array}$ & $\begin{array}{l}.70^{* *} \\
(.25)\end{array}$ & $\begin{array}{l}.68^{*} \\
(.29)\end{array}$ & & $\begin{array}{l}.67 * * \\
(.28)\end{array}$ \\
\hline Border War, impact & & & & $\begin{array}{l}7.89 * * \\
(3.21)\end{array}$ & & $\begin{array}{c}7.89^{*} \\
(3.43)\end{array}$ & $\begin{array}{c}7.88^{* * *} \\
(3.24)\end{array}$ \\
\hline Border War, decay & & & & $\begin{array}{c}-.35 \\
(.31)\end{array}$ & & $\begin{array}{l}-.35 \\
(.33)\end{array}$ & $\begin{array}{l}-.35 \\
(.31)\end{array}$ \\
\hline Prospective evaluations & & & $\begin{array}{c}.08^{*} \\
(.03)\end{array}$ & & & & \\
\hline Constant & $\begin{array}{l}55.5^{* *} \\
(6.68)\end{array}$ & $\begin{array}{l}33.8 \\
(33.52)\end{array}$ & $\begin{array}{l}54.1 * * \\
(8.33)\end{array}$ & $\begin{array}{l}34.9 \\
(31.48)\end{array}$ & $\begin{array}{c}55.3^{* *} \\
(6.69)\end{array}$ & $\begin{array}{l}55.6^{* *} \\
(6.88)\end{array}$ & $\begin{array}{l}55.2^{* *} \\
(7.01)\end{array}$ \\
\hline Autoregressive parameter & $\begin{array}{l}.93 * * \\
(.04)\end{array}$ & $\begin{array}{l}.88^{* *} \\
(.05)\end{array}$ & $\begin{array}{l}.93 * * \\
(.04)\end{array}$ & $\begin{array}{l}.89 * * \\
(.05)\end{array}$ & $\begin{array}{l}.93 * * \\
(.04)\end{array}$ & $\begin{array}{l}.93 * * \\
(.04)\end{array}$ & $\begin{array}{l}.94 * * \\
(.04)\end{array}$ \\
\hline Centered $\mathrm{R}^{2}$ & .86 & .88 & .89 & .90 & .87 & .87 & .88 \\
\hline
\end{tabular}

Note: Standard errors are in parentheses. Significance tests are one-tailed: ${ }^{*} p \leq .05 ; * * p \leq .01$.

tant for Fujimori's popularity, but it also had a measurable long-term influence. Although contradicting other statistical analysis, these results support the widely held view that Guzmán's capture caused an important increase in Fujimori's popularity from which he continued to benefit for some time (McClintock 1999; Panfichi 1997).

Turning to the 1992 autogolpe, I again expect the intervention analysis to confirm the assertions of numerous scholars that the autogolpe precipitated an increase in Fujimori's popularity (Panfichi 1997; Stokes 1996; Weyland 2000). The analysis supports my expectations. Depending on the exact model, Fujimori's approval increased by about 15 points in the month following the self-coup, and the model-estimated decay rate is around .70 . Assuming the estimated .70 rate of decay, the effect of the self-coup falls below one point within a year and approaches zero after two.

Therefore, although the initial impact of the self-coup is estimated to be greater than that of the capture of the Sendero leaders, the influence of the arrests seems to persist much longer, continuing to influence approval years after the event, while the boost from the autogolpe dissipates more rapidly. This result is encouraging for vertical accountability. Even though Fujimori may have been rewarded initially for his anticonstitutional acts in 1992, he did not enjoy inflated popular- 
ity for a long time as a result. Rather, the public quickly returned to its initial level of support, not being fooled for long by his dramatic, authoritarian actions. Alternatively, the public continued rewarding Fujimori with increased approval levels years after the capture of the Sendero leaders. Perhaps this can be attributed to people acknowledging the real, positive, and long-term influence the arrests had on their lives and choosing to support Fujimori as a result.

In addition to the capture of Guzmán and the self-coup, several events related to the 1995 border conflict with Ecuador, such as its onset, its conclusion, and the 1998 peace agreement, were examined as possible interventions. Among these, only a variable accounting for the onset of the conflict was found to have a significant effect. In accord with the idea that the rally-around-the-flag phenomena yields public support at the outset of a conflict, Fujimori's approval increased by approximately eight points in the first survey after the clash began. However, in this case the decay rate is not significantly different from zero. This essentially means that although Fujimori's popularity was temporarily bolstered by the onset of the border war, the effect was fleeting. In the succeeding month, the impact of the conflict on approval was not significant.

I also assessed whether or not Fujimori's reelection or events related to the invasion of the Japanese ambassador's residence by the Tupac Amaru guerrillas influenced presidential approval. These interventions were not found to have significant effects so they are excluded from further analysis.

THE ECONOMY AND PRESIDENTIAL APPROVAL: A TIME-SERIES REGRESSION ANALYSIS. ${ }^{11}$ Having explored the influence of certain political events on presidential approval, I turn to the question of how the economy and economic evaluations affect presidential approval. Because the models considered here are complex, transfer function analysis is inadequate, and other modeling approaches must be explored.

Here the best alternative is an approach enabling specification of dynamic causation while accounting for serial correlation: ordinary least squares regression (OLS) with a lagged dependent variable. The selection of this method is driven by the theory that the relationship between economics and political assessments is dynamic (Durr, Gilmour, and Wolbrecht 1997). The economy and economic evaluations do not exert all their influence on presidential approval in a single period. Rather, they continue to have a residual impact even at considerable lags. The presidential approval series has a memory - past values shape current ones. ${ }^{12}$ Thus, I specify dynamic causation. ${ }^{13}$

\footnotetext{
${ }^{11}$ This analysis was conducted using STATA, version 6.0.

${ }^{12}$ For more information on infinite-order, distributed lag models, see Wood (1992).

${ }^{13} \mathrm{~A}$ model that only accounts for static causation is inadequate and may lead to serious specification error, which results in considerably biased and inefficient parameter estimates. In the interest of full disclosure, it is necessary to point out that estimates generated using the lagged dependent variable approach may also produce biased estimates. However, the bias produced using the lagged dependent variable model is trivial, going to zero as the sample size increases (Greene 2000). Therefore, the method is not only theoretically desirable, but also statistically appropriate.
} 
TABLE 2

Presidential Approval in Peru-Monthly Time-Series Regression ${ }^{\text {a }}$

\begin{tabular}{|c|c|c|c|c|}
\hline \multirow[b]{2}{*}{ Independent Variable } & \multicolumn{4}{|c|}{ Presidential Approval } \\
\hline & 1 & 2 & 3 & 4 \\
\hline Approval $_{t-1}$ & $\begin{array}{l}.90^{* *} \\
(.04)\end{array}$ & $\begin{array}{l}.91^{* *} \\
(.04)\end{array}$ & $\begin{array}{l}.91^{* *} \\
(.04)\end{array}$ & \\
\hline Prospective evaluations & & & $\begin{array}{l}.15^{* *} \\
(.05)\end{array}$ & $\begin{array}{l}.06^{*} \\
(.04)\end{array}$ \\
\hline Retrospective evaluations & & $\begin{array}{l}.07 \\
(.05)\end{array}$ & $\begin{array}{l}.01 \\
(.05)\end{array}$ & $\begin{array}{l}.01 \\
(.03)\end{array}$ \\
\hline Inflation & $\begin{array}{l}.20 \\
(.37)\end{array}$ & $\begin{array}{l}.24 \\
(.37)\end{array}$ & $\begin{array}{l}.27 \\
(.35)\end{array}$ & $\begin{array}{l}.00 \\
(.67)\end{array}$ \\
\hline Change in GDP & $\begin{array}{l}.00 \\
(.00)\end{array}$ & $\begin{array}{l}.00 \\
(.00)\end{array}$ & $\begin{array}{l}.00 \\
(.00)\end{array}$ & $\begin{array}{l}.00 \\
(.00)\end{array}$ \\
\hline Self-Coup & $\begin{array}{l}16.09 * * \\
(4.49)\end{array}$ & $\begin{array}{l}15.02 * * \\
(4.52)\end{array}$ & $\begin{array}{l}13.55^{* *} \\
(4.38)\end{array}$ & $\begin{array}{c}8.13^{*} \\
(3.67)\end{array}$ \\
\hline Sendero capture & $\begin{array}{l}10.60 * * \\
(4.48)\end{array}$ & $\begin{array}{l}11.15^{* *} \\
(4.47)\end{array}$ & $\begin{array}{l}11.37 * * \\
(4.30)\end{array}$ & $\begin{array}{l}8.09 * * \\
(3.38)\end{array}$ \\
\hline Border conflict & $\begin{array}{l}10.89 * * \\
(4.51)\end{array}$ & $\begin{array}{l}11.00^{* *} \\
(4.48)\end{array}$ & $\begin{array}{l}11.35^{* *} \\
(4.31)\end{array}$ & $\begin{array}{l}8.29 * * \\
(3.35)\end{array}$ \\
\hline Constant & $\begin{array}{l}4.58^{*} \\
(2.05)\end{array}$ & $\begin{array}{l}4.54^{*} \\
(2.04)\end{array}$ & $\begin{array}{r}4.14^{*} \\
(1.96)\end{array}$ & $\begin{array}{l}56.55^{* *} \\
(6.48)\end{array}$ \\
\hline $\mathrm{R}^{2}$ & .89 & .89 & .90 & .31 \\
\hline $\begin{array}{l}\text { Adj. } R^{2} \\
\text { rho }\end{array}$ & .88 & .88 & .89 & $\begin{array}{l}.26 \\
.94\end{array}$ \\
\hline $\begin{array}{l}\text { Model Significance } \\
\text { Number of cases }=100\end{array}$ & .00 & .00 & .00 & .00 \\
\hline
\end{tabular}

Note: Standard errors are in parentheses. Significance tests are one-tailed: $* p \leq .05 ; * * p \leq .01$.

${ }^{a}$ Models 1, 2, and 3 display the results of OLS regression, and Model 4 depicts those of feasible generalized least squares analysis.

The first three columns in Table 2 display the results of the OLS analyses, beginning with the simplest conceptualization of the relationship between the economy and presidential approval and ending with the most complex. ${ }^{14}$ All models use pulse dummy variables to account for the significant intervention effects discussed above: the capture of Sendero leaders, the self-coup, and the onset of the border war with Ecuador. ${ }^{15}$ Column 1 shows the relationship between

\footnotetext{
${ }^{14}$ The lagged dependent variable specification is likely to be biased in the direction of overstating its impact while reducing the estimated influence of other explanatory variables. Therefore, this is a conservative test of the hypotheses.

${ }^{15}$ Using pulse dummy variables to model the effects of events enables the analyst to account for the resulting sudden changes in approval. The coefficient for each event represents its initial impact; the decay parameters are absorbed in a single decay factor-the lagged dependent variable. The coefficients and decay parameter estimated using regression fall within two standard deviations of the intervention analysis point estimates.
} 
the indicators of the real economy and presidential approval. Contrary to our expectations, neither inflation nor change in GDP has significant relationship with presidential approval. ${ }^{16}$ However, given the lack of consensus in the literature about the direct influence of the real economy on approval (Monroe 1978; Norpoth and Yantek 1983) and the primary role of these variables as control factors, these results are neither problematic nor surprising.

Columns 2 and 3 display the relationships between the different economic evaluations and presidential approval, controlling for the real economy. Column 2 presents the relationship between retrospective evaluations and presidential approval. Although the coefficient for retrospective evaluations is in the expected direction, its significance as a predictor directly influencing presidential approval is questionable $(p \leq .10)$. Also, as in the first model, we do not find significant effects for inflation or GDP. ${ }^{17}$

However, examination of column 3 reveals that all types of economic evaluations are not insignificant in understanding presidential approval in Peru. Prospective economic evaluations have a significant influence on presidential approval ( $\beta=.15, p \leq .01$ ), when controlling for retrospective evaluations and the real economy. With a positive change of one point on the prospective evaluations index, presidential approval increases by .15 percentage points. To put it in terms of the data at hand, when prospective evaluations increase from 119 in April 1994 to 131 in May, approval should rise by about 1.8 percentage points, and, in fact, approval increases from $61 \%$ to $63 \%$.

Inflation, retrospective evaluations, and differenced GDP have no significant effects. However, additional analysis indicates that retrospective evaluations $(\beta=.36, p \leq .01)$ and inflation $(\beta=-2.62, p \leq .01)$ are significant predictors of prospective evaluations. This demonstrates that prospective evaluations incorporate information about the real economy, evaluations of past economic performance, as well as expectations about the future. So although retrospective evaluations and inflation do not directly affect approval levels, they are important and can be said to indirectly influence approval through their effect on prospective evaluations. ${ }^{18}$

In order to establish that the above results are not peculiar to the lagged dependent variable specification, I reexamine the final model, using Prais-Winsten (1954) feasible generalized least squares (FGLS). ${ }^{19}$ The strengths and weaknesses

\footnotetext{
${ }^{16}$ Using a deseasonalized measure of GDP produces essentially the same results.

${ }^{17}$ Retrospective evaluations were also tested without controlling for inflation and GDP in order to allow for the possibility that the inclusion of these variables, which indirectly tap retrospective evaluations, might confound the effects of retrospective evaluations themselves. However, even when these controls are removed from the model, the Retrospective Evaluations Index has an insignificant effect: $\beta=.07$, s.e. $=.04, p \leq .10$.

${ }^{18}$ Other analysis shows that both inflation $(\beta=-2.6, p \leq .05)$ and GDP $(\beta=.001, p \leq .05)$ are significant predictors of retrospective evaluations. This leads me to believe that as expected the real economy is important in shaping retrospective evaluations.

${ }^{19}$ Despite using the lagged dependent variable as a predictor in the first three models, calculation of Durbin's (1970) h statistic, which tests for serial correlation of errors when lagged values of
} 
of the Prais-Winsten technique complement those of the lagged dependent variable approach. While FGLS cannot account for dynamic causal processes, the OLS assumption of uncorrelated errors is not required. Column 4 of Table 2 presents the Prais-Winsten estimates. Comparing these results to those found in column 3 indicates that there are no substantive differences between the estimates produced using OLS and those produced by FGLS. ${ }^{20}$ Again, prospective evaluations have a significant and positive influence on presidential approval, while the other economic predictors are insignificant.

These findings support the idea that the economy is important in shaping public opinion of the president in Peru. Of particular interest is the evidence indicating that prospective evaluations directly and systematically shape presidential approval over time. Prospective evaluations influence approval even when controlling for the real economy and retrospective economic evaluations. The above findings also provide evidence that when forming prospective evaluations, Peruvians draw upon retrospective evaluations, current economic indicators, and additional information concerning the future economic situation. They then use these future-oriented evaluations in determining whether they approve of the president or not.

One final point concerning the regression analysis pertains to the political event dummy variables: the self-coup, the capture of Sendero leaders, and the border war. In each of the model specifications, all three event variables are significant $(p \leq .01)$. Furthermore, their initial effects estimated with regression closely resemble those established with the intervention analysis. As presented in column 3 of Table 2, the regression analysis estimates that the self-coup boosted approval by about 15 percentage points, the Sendero arrests by 11 points, and the border war by 11 points. ${ }^{21}$ These results corroborate the importance of certain events in boosting Fujimori's popularity.

\section{Conclusions}

This article examines the factors that influence Peruvian presidential approval and makes three contributions. First, the article strengthens and extends economic

the dependent variable are used as predictors, indicates that serial correlation persists in the error term. The $\mathrm{h}$ statistic for Model 3 in Table 2 is $-.29, \mathrm{p}=.02$, signifying that we cannot accept the null hypothesis of no serial correlation. The succeeding FGLS model eliminates serial correlation in the errors.

${ }^{20} \mathrm{~A}$ different approach for dealing with serially correlated errors is to include a second lag $\left(\mathrm{y}_{\mathrm{t}-2}\right)$ of the dependent variable as a predictor. Doing so produces the same substantive results as those displayed in Table 2 with prospective evaluations being the only significant economic predictor $(\beta=.15$, $p \leq .01)$. The coefficient on the second lag of presidential approval is .21 and significant at the .05 level. Durbin's h statistic $(-.22, p=.27)$ calculated for this model indicates that the serial correlation has been eliminated.

${ }^{21}$ The common decay parameter, or the coefficient of the lagged dependent variable, for the OLS models is about 9. This decay rate lies within two standard deviations of the intervention analysis estimates for the Sendero capture and the self-coup. Only the border war is misrepresented under this decay rate, but I leave it in the model to control for its impact. 
theories of approval by contributing to the ongoing debate about retrospective and prospective evaluations. Because economic theories of presidential approval have been formulated and primarily applied in advanced, industrialized countries, subjecting them to the rigorous test presented by the political and economic uncertainty of a developing nation like Peru enables us to understand the breadth of their applicability and the depth of their explanatory power. The preceding analysis provides support for the idea that Peruvians, like the people of advanced industrial countries, employ economic evaluations to assess the president. Specifically, Peruvians use prospective evaluations, incorporating evaluations of the past, current information, and expectations about the future. This finding indicates that despite the educational disadvantages and economic and political complexities faced by Peruvians, prospective economic accountability is possible in the developing world. Furthermore, extending economic theories to nations outside the developed world demonstrates their wide relevance in understanding accountability.

Second, we learn that accountability is possible, even in delegative democracies like Peru. The analysis indicates that Peruvians exercise both political and economic accountability. Political accountability is evidenced by changes in approval due to important events, namely the capture of the Sendero leaders, the self-coup, and the border conflict. Of these events, the Sendero capture had the most enduring influence, suggesting that people responded to the positive, longterm changes in their lives that the arrests precipitated. Conversely, neither the self-coup nor the border conflict brought about such a lasting response from the public, which suggests that the Peruvian public not only considers political events when assessing the president, but also seems to distinguish between significant, positive change and temporary posturing. The analysis also presents evidence that the economy provides a systematic foundation for presidential approval. In particular, Peruvians appraise the president's performance using prospective evaluations.

The public holds the president to task for both politics and economics, and this link provides some measure of vertical accountability. Even though the weakness of democratic institutions in delegative democracies like Peru limit representation and accountability in these polities, this analysis indicates that some accountability is possible. This finding is significant as it addresses the extent to which representation and accountability may occur in the many delegative democracies throughout Latin America and the rest of the world. At the very least, people can derive systematic assessments of their president based on political and economic outcomes. In this way, even the powerful leaders of delegative democracies are accountable to public opinion for their actions.

Finally, this article speaks to the feasibility of different economic policies. The finding that people use prospective evaluations in assessing the president indicates that the public is forward-looking. Although past actions matter in developing prospective evaluations, Peruvians also care about the future repercussions of these actions. A prospective public pushes politicians to consider both immediate and lasting effects of their policies, thereby encouraging more responsible 
choices. Such a public will be more willing to endure temporary hardship if it is expected to bring future prosperity.

The practical implications that follow from the possibility that the citizenry in developing countries like Peru formulate and employ prospective evaluations in assessing the president are extremely significant. Consider the case of the austerity programs that have been broadly imposed by international financial institutions on struggling economies throughout Latin America and the rest of the developing world. The political unrest that often accompanies such programs is less likely to develop if the public uses prospective evaluations and calculates that long-term benefits will outweigh short-term costs. Essentially, this means that austerity programs are politically viable and will not necessarily undermine government or regime legitimacy, provided the people expect the programs to bring future gains that compensate for current sacrifices.

Therefore, by exploring issues of economic and political accountability in Fujimori's Peru, this article exhibits the relevance of theories of economic accountability in the volatile context of the developing world, demonstrates that some form of accountability is possible in the now prevalent delegative type of democracy, and throws light on the political feasibility of different economic programs.

\section{Manuscript submitted 14 January 2002}

Final manuscript received 3 September 2002

\section{References}

Apoyo, S.A. 1992. Political and Economic Situation in Lima, Peru, January 1992-December 1994. The Roper Center.

Apoyo, S.A. December 1991; January 1995-April 2000. Informe de Opinión [Survey Report]. Lima: Apoyo.

Box, G.E.P. and G.C. Tiao. 1975. "Intervention Analysis with Applications to Economic and Environmental Problems." Journal of the American Statistical Association 70(1): 70-79.

Burt, Jo-Marie. 1997. "Political Violence and the Grassroots in Lima, Peru." In The New Politics of Inequality in Latin America: Rethinking Participation and Representation, eds. Chalmers et al. New York: Oxford University Press.

Chappell, Henry W., Jr., and William R. Keech. 1985. "A New View of Political Accountability for Economic Performance." American Political Science Review 79(1): 10-27.

Conover, Pamela Johnston, Stanley Feldman, and Kathleen Knight. 1987. "The Personal and Political Underpinnings of Economic Forecasts." American Journal of Political Science 31(3): 559-83.

Contreras, Carlos, and Marcos Cueto. 1999. Historia del Perú Contemporáneo [History of Contemporary Peru]. Lima: Red para el Desarrollo de las Ciencias Sociales.

Duch, Raymond M. 1995. "Economic Chaos and the Fragility of Democratic Transition in Former Communist Regimes." Journal of Politics 57(1): 121-58.

Durbin, J. 1970. "Testing for Serial Correlation in Least-Squares Regression When Some of the Regressors Are Lagged Dependent Variables.” Econometrica 38(3): 410-21.

Durr, Robert H., John B. Gilmour, and Christina Wolbrecht. 1997. "Explaining Congressional Approval." American Journal of Political Science 41(1): 175-207.

Erickson, Robert S., Michael B. MacKuen, and James A. Stimson. 2002. The Macro Polity. Cambridge: Cambridge University Press. 
Eulau, Heinz, and Michael Lewis-Beck, eds. 1985. Economic Conditions and Electoral Outcomes. New York: Agathon.

Fiorina, Morris P. 1981. Retrospective Voting in American National Elections. New Haven: Yale University Press.

Greene, William H. 2000. Econometric Analysis, 4th ed. Upper Saddle River, NJ: Prentice Hall.

Hibbs, Douglas. 1987. The American Political Economy. Cambridge: Harvard University Press.

Instituto Nacional de Estadística e Informática [National Institute of Statistics and Information]. 2001. Peru: Compendio de estadísticas economicas y financieras [Peru: Compendium of Economic and Financial Statistics]. <http://www.inei.gob.pe> (Accessed 16 January 2001).

Kaufman, Robert R., and Leo Zuckerman. 1998. "Attitudes toward Economic Reform in Mexico: The Role of Political Orientations." American Political Science Review 92(2): 359-75.

Key, Valdimer O., Jr. 1966. The Responsible Electorate: Rationality in Presidential Voting, 1936-1960. Cambridge, MA: Belknap.

Kinder, Donald R. 1981. "Presidents, Prosperity and Public Opinion." Public Opinion Quarterly 45(1): $1-21$.

Kinder, Donald R., and Roderick Kiewiet. 1981. "Sociotropic Politics: The American Case." British Journal of Political Science 11(2): 129-61.

Klepak, Hal. 1998. Confidence Building Sidestepped: The Peru-Ecuador Conflict of 1995. Toronto: Centre for International and Security Studies and FOCAL.

Kuklinski, James H., and Darrell M. West. 1981. "Economic Expectations and Voting Behavior in United States House and Senate Elections." American Political Science Review 75(2): 436-47.

Lewis-Beck, Michael. 1985. "Pocketbook Voting in U.S. National Election Studies: Fact or Artifact?" American Journal of Political Science 29(2): 348-56.

Lewis-Beck, Michael. 1988. Economics and Elections. Ann Arbor: University of Michigan Press.

MacKuen, Michael B., Robert S. Erickson, and James A. Stimson. 1992. "Peasants or Bankers? The American Electorate and the U.S. Economy." American Political Science Review 86(3): 597-611.

Marcella, Gabriel, and Richard Downes, eds. 1999. Security Cooperation in the Western Hemisphere: Resolving the Ecuador-Peru Conflict. Miami: North-South Center.

McClintock, Cynthia. 1998. Revolutionary Movements in Latin America: El Salvador's FMLN and Peru's Shining Path. Washington, DC: U.S. Institute of Peace.

McClintock, Cynthia. 1999. "Peru: Precarious Regimes, Authoritarian and Democratic." In Democracy in Developing Countries: Latin America, 2nd ed., eds. Larry Diamond et al. Boulder, CO: Lynne Rienner.

Monroe, Kristin. 1978. "Economic Influences on Presidential Popularity." Public Opinion Quarterly 42(3): 360-69.

Norpoth, Helmut, and Thom Yantek. 1983. "Macroeconomic Conditions and Fluctuations of Presidential Popularity: The Question of Lagged Effects.” American Journal of Political Science 27(4): 785-807.

O’Donnell, Guillermo. 1999. Counterpoints: Selected Essays on Authoritarianism and Democratization. Notre Dame, IN: University of Notre Dame Press.

Pacek, Alexander C. 1994. "Macroeconomic Conditions and Electoral Politics in East Central Europe." American Journal of Political Science 38(3): 723-44.

Pacek, Alexander C., and Benjamin Radcliff. 1995. "The Political Economy of Competitive Elections in the Developing World.” American Journal of Political Science 39(3): 745-59.

Panfichi, Aldo. 1997. "The Authoritarian Alternative: 'Anti-Politics' in the Popular Sectors of Lima." In The New Politics of Inequality in Latin America, eds. Chalmers et al. New York: Oxford University Press.

Prais, G. J., and C. B. Winsten. 1954. "Trend Estimators and Serial Correlation.” Cowles Commission Discussion Paper No. 383.

Przeworski, Adam. 1991. Democracy and the Market: Political and Economic Reforms in Eastern Europe and Latin America. New York: Cambridge University Press. 
Remmer, Karen. 1991. "The Political Impact of Economic Crisis in Latin America in the 1980s." American Political Science Review 85(3): 777-800.

Remmer, Karen. 1993. "The Political Economy of Elections in Latin America, 1980-1991." American Political Science Review 87(2): 393-407.

Sartori, Giovanni. 1987. The Theory of Democracy Revisited. Chatham: Chatham House.

Schedler, Andreas. 1999. "Conceptualizing Accountability." In The Self-Restraining State, eds. Andreas Schedler, Larry Diamond, and Marc Plattner. Boulder, CO: Lynne Rienner.

Schedler, Andreas, Larry Diamond, and Marc Plattner, eds. 1999. The Self-Restraining State. Boulder, CO: Lynne Rienner.

Seligson, Mitchell A., and Miguel Gómez B. 1989. "Ordinary Elections in Extraordinary Times: The Political Economy of Voting in Costa Rica." In Elections and Democracy in Central America, eds. John A. Booth and Mitchell A. Seligson. Chapel Hill: University of North Carolina Press.

Shapiro, Robert Y., and Bruce M. Conforto. 1980. "Presidential Performance, the Economy and the Public's Evaluation of Economic Conditions." Journal of Politics 42(1): 49-67.

Stokes, Susan C. 1996. "Economic Reform and Public Opinion in Peru, 1990-1995." Comparative Political Studies 29(5): 544-65.

Stokes, Susan C. 1999. "What Do Policy Switches Tell Us about Democracy?" In Democracy, Accountability and Representation, eds. Adam Przeworski, Susan C. Stokes, and Bernard Manin. Cambridge: Cambridge University Press.

Weyland, Kurt. 1998. "Peasants or Bankers in Venezuela? Presidential Popularity and Economic Reform Approval, 1989-1993." Political Research Quarterly 51(2): 341-62.

Weyland, Kurt. 2000. "A Paradox of Success? Determinants of Political Support for President Fujimori." International Studies Quarterly 44(3): 481-502.

Wood, B. Dan. 1992. "Modeling Federal Implementation as a System: The Clean Air Case." American Journal of Political Science 36(1): 40-67.

Jana Morgan Kelly is a Ph.D. candidate in political science, University of North Carolina at Chapel Hill, Chapel Hill, NC 27599-3265. 